\title{
Quatro olhares sobre Angola: entrevistas com Boaventura Cardoso, Pepetela, José Eduardo Agualusa e Ondjaki
}

\author{
LUARA PINTO MINUZZI \\ Pontifícia Universidade Católica do Rio Grande do Sul
}

Boaventura Cardoso, Pepetela, José Eduardo Agualusa e Ondjaki: quatro escritores angolanos com inúmeros livros publicados e fama tanto no seu país, quanto no exterior; quatro autores preocupados com a realidade - nem sempre muito fácil - de Angola, trazendo seu presente e passado para dentro da ficção. Quatro intelectuais pertencentes a duas gerações distintas e significativas da história recente da ex-colônia portuguesa: Boaventura Cardoso e Pepetela, por um lado, daquela geração dos que viveram a Guerra de Libertação de Angola e que combateram a dominação lusa; Agualusa e Ondjaki, por outro, de uma geração mais nova, tendo o primeiro 15 anos quando da independência e o segundo nascido dois depois do fim do colonialismo.

Apesar de todos esses pontos em comum, suas trajetórias de vida apresentam inúmeros aspectos distintos e, até mesmo divergentes. Boaventura Cardoso, primeiro, desde os anos 1960, quando eclodiu a guerra, envolveu-se com o estabelecimento da nova nação, tendo combatido clandestinamente os colonos portugueses e se envolvido com política desde a independência: começando como diretor do Instituto Nacional do Livro e secretário de Estado da Cultura, o autor também ocupou os cargos de Ministro da Informação, embaixador de Angola em três diferentes países, além de governador da província de Malanje. Sua obra literária é composta por livros de contos e romances. O signo do fogo, Maio, mês de Maria e Mãe, materno mar retratam, respectivamente, a Guerra de Libertação, a repressão do regime instaurado após a independência e o momento posterior à virada do socialismo para o capitalismo ocorrida na década de 1980.

Depois, Pepetela, como guerrilheiro, foi para o epicentro da guerra e empunhou armas, além da caneta do protesto, e, a partir das suas experiências, escreveu livros como As aventuras de Ngunga e o aclamado Mayombe, que aborda, de forma crítica, os sucessos e problemas do Movimento Popular de Libertação de Angola, um dos grupos que combateu o colonialismo. Como Boaventura Cardoso, ele ocupou alguns cargos de destaque depois de 1975, como o de vice-ministro da Educação e o de diretor da União dos Escritores Angolanos. Contudo, ao contrário do outro escritor, Pepetela deixou cedo a vida política para se dedicar à literatura. Sua extensa obra, entre romances e contos, contempla a história de Angola desde tempos remotos, como Lueji, que remonta ao século XVII, até o presente e, até mesmo o futuro, quando, em $O$ quase fim do mundo, o autor imagina uma hecatombe que dizima a maior parte da população do mundo.

Agualusa e Ondjaki, por outro lado, nunca exerceram cargos políticos e - como fica claro a partir de suas entrevistas - também não têm pretensões de algum dia exercer. O primeiro, apesar de não morar mais em Angola há muitos anos e de ter enfrentado problemas com o regime no poder, nunca deixou de retratar a realidade de seu país, como em seus romances históricos A rainha Ginga, A conjura e Nação crioula. Sua visão condenatória e ácida do governo do MPLA, no poder desde a independência, pode ter the rendido inimigos poderosos, porém acabou por transformar a sua obra numa referência para qualquer um que deseje entender melhor os trilhos percorridos pela nação nessas últimas décadas.

Ondjaki, por sua vez, traz um olhar diferente para a realidade angolana com seus narradores crianças dos romances Bom dia camaradas e AvóDezanove e o segredo do soviético e do livro de contos Os da minha rua. Porém, apesar da visão mais inocente, seus textos não deixam de ser críticos e de mostrar a realidade de um país assolado pela Guerra Civil - o que acontece é a não folclorização: Ondjaki consegue apresentar uma África que passa sim por muitos problemas, mas que não é aquela, mostrada nos veículos de comunicação, onde só desastres e calamidades ocorrem. Em Luanda, cidade onde os personagens vivem, é possível brincar, rir e sonhar - e não apenas sofrer e desesperar.

Levando em consideração o rico panorama de semelhanças e diferenças entre os quatro escritores, a intenção destas entrevistas foi a busca de uma compreensão da visão dessas duas gerações de intelectuais e escritores sobre a realidade de Angola, sobre seu passado de guerras e de conflitos, sobre as expectativas para o futuro, assim como sobre as peculiaridades do continente africano e das suas cultura e tradição. Assim, algumas questões base foram feitas para os quatro escritores. Outras, focadas na vida e na obra de cada um, acabaram por se diferenciar. Todas as entrevistas foram realizadas por e-mail entre junho de 2016 e maio de 2017. As perguntas foram encaminhadas individualmente para cada um dos autores, que se encontravam em diferentes cantos do mundo: Angola, Portugal, Moçambique. 


\section{BOAVENTURA CARDOSO}

LuARA Minuzzi (LM) - Gostaria de começar por Mãe materno mar. Se o comboio, com seus vagões de primeira, segunda e terceira classes, representa Angola, a quantidade de anos que a viagem dura, 15 , tem algum significado especial do ponto de vista histórico?

Boaventura Cardoso (BC) - Acho que sim. Porquê é que a viagem dura quinze anos? Na minha simbologia literária a numerologia ocupa um lugar particular. Em quase toda a minha obra, sobretudo nos romances, vai encontrar números ímpares, nomeadamente, o três, o sete e o treze. Desde os primórdios da humanidade, os números encerram mitos e uma mística própria. Na Bíblia Sagrada encontramos várias alusões a números. Até hoje há o mito de que a sexta-feira treze é um mau dia. Não me passou despercebido o facto de o número quinze resultar do três vezes cinco.

LM - Também gostaria de saber se a escolha pelo comboio e pela viagem de comboio para situar a narrativa tem algum sentido especial.

BC - De facto, o comboio é, alegoricamente, Angola a serpentear por vales e montanhas, a subir e a descer. O país a enfrentar estoicamente a guerra, a sobreviver apesar dela. Era preciso fazer a guerra para acabar com ela; não havia outra alternativa. Para além disso, a viagem proporciona sempre a descoberta de outras realidades; viajar é conhecer o outro e, através dele, conhecer-monos a nós próprios. Portanto, quando se viaja não há só uma deslocação ou deslocalização espacial e física mas também mental.

LM - Percebo algumas semelhanças entre a sua biografia e alguns elementos do livro. $O$ senhor, por exemplo, saiu quando era jovem de Malanje e foi para Luanda - assim como a viagem do romance. Além disso, o seu casamento foi oficiado pelo bispo de Ndalatando - e, na narrativa, o grande casamento da Noiva deveria ocorrer nessa localidade. Há outros paralelos além desses? $\mathrm{E}$ se a jornada de Mãe, materno mar representa a de Angola após a independência, há um paralelo entre essa jornada da nação e a do Boaventura Cardoso?

BC - De facto, no romance, o jovem Manecas é, em certa medida, um pouco de mim. Quando vivia em Malanje, durante as férias, fazia sempre o percurso MalanjeLuanda e vice-versa. Mas quando morreu o meu pai, em 1967, fiz esse percurso com o único propósito de encontrar emprego em Luanda, o que felizmente consegui nos Serviços de Fazenda e Contabilidade. Deixei a minha mãe ainda enlutada e em pranto. Em Malanje conheci a minha futura noiva com quem me iria casar em 1970.
Quando o personagem Manecas chega a Luanda e vê o mar pela primeira vez, vai logo mergulhar seus pés nele. Com esse gesto, regressa (simbolicamente) ao regaço materno.

LM - Apesar dos muitos problemas enfrentados, o trem chega ao seu destino, Luanda. Eu vejo esse final como bastante esperançoso. $O$ que o senhor acha disso? Também fico pensando no ano da publicação do livro, 2001, pouco antes do fim da Guerra Civil. A aproximação do fim da guerra tem relação com esse final de esperança. E o senhor é otimista em relação ao presente e ao futuro de Angola 15 anos após a publicação do romance?

BC - Diria mesmo que os finais dos meus romances são sempre esperançosos. Acredito piamente que depois da tempestade vem a bonança. Quando dei por concluído o romance, em Agosto de 2000, já havia uma luz ao fundo do túnel. Pressentia que o fim da longa guerra estava quase a chegar ao fim.

LM - Em um entrevista publicada no livro Boaventura Cardoso, a escrita em processo, o senhor fala que escreveu uma tese sobre o fenômeno religioso em Luanda e centrou-se nos ritos funerários. Esse trabalho está publicado em algum livro? O senhor poderia falar mais sobre esse trabalho e sobre qual é a sua ideia? Minha tese foca-se justamente na questão da morte, então fiquei bastante interessada.

BC - Não, a minha tese de licenciatura não foi publicada. Penso fazê-lo um dia depois de revista e melhorada. Dissertei nessa tese sobre o ritos funerários na cidade de Luanda.

É um fenómeno social complexo que tem na sua origem dois factos importantes. Primeiro, a entrada em Angola de muitas igrejas de matriz africana proveniente do antigo Zaire, hoje República Democrática do Congo. Segundo, devido à guerra que assolou todo o país, houve uma forte migração das populações do interior para os centros urbanos, nomeadamente, Luanda. A guerra, como sempre, desestabiliza, desintegra famílias, cria desemprego pobreza e miséria. Então, pressionadas pela crise social que se instala, as pessoas recorrem a essas igrejas que prometem o céu e a lua, para além de apregoarem que fazem curas e milagres. É comum ouvir-se dizer que "Deus ajuda, mas demora". Como as igrejas ditas africanas aparentam ser mais céleres na solução de problemas, têm a adesão assegurada de muita gente de todas as camadas sociais. Deste modo, há muita gente que, sem renunciar às igrejas mais antigas e enraizadas na sociedade angolana, como a Católica e as Evangélicas, migraram transitoriamente para tais igrejas africanas em busca de solução rápida para os seus problemas. 
Esse quadro social, alterou profundamente os ritos funerários na cidade capital. Por exemplo, quando dos funerais nas comunidades de angolanos vindos do antigo Zaire, habitualmente designados por "regressados" ou "retornados", o caixão é atirado ao ar por homens possantes; usam-se bandas de música; antes, tem de se saber qual a causa da morte, mesmo quando se tem conhecimento que o finado padecia desta ou daquela doença; o defunto é, assim, sujeito a um "interrogatório" sobre o motivo ou motivos do seu desaparecimento físico; a viúva é espoliada dos bens gerados pelo casal, em proveito de tios e sobrinhos do marido. Vale aqui dizer que, mesmo quando natural, a morte estabelece a desordem ao nível da consciência colectiva, pois ela tem de ter sempre uma causa social.

A sociedade luandense tem uma dinâmica própria; em função de mudanças sócio-culturais, mudaram-se os hábitos e práticas rituais funerárias. Pelos óbitos se pode inferir se o defunto era alguém de grandes posses ou de grandes famílias ou um humilde zé ninguém. Assim, nos grandes funerais aparecem altos dirigentes, generais e importantes homens de negócios; as senhoras ostentam o que de mais luxuoso têm; depois, para o "komba ditókua" (cerimónia tradicional de encerramento do óbito), são contratadas empresas de restauração que servem de tudo. Antigamente, o "komba" era uma cerimónia simples e modesta; as iguarias eram as tradicionais, preparadas por senhoras da comunidade; as bebidas também.

Finalmente, devo dizer que o homem africano é crente por vocação, pelo que tem do universo uma visão espiritualista e mística. Ele vive assim entre dois mundoso visível e o invisível - em que Deus é sempre a causa primeira.

Profundamente impregnado de religiosidade, submerso na sua casualidade mística, o africano bantu é detentor de uma "fé mágica" através da qual expressa a sua espiritualidade. Assim, entre os bantu, é frequente e comum, a religião e a magia aparecerem interligadas. Embora a religião seja superior à magia, esta é parte integrante da mentalidade religiosa do africano em geral. Disso resulta que, em presença de certas práticas mágicoreligiosas, não seja fácil estabelecer limites entre religião, magia, feitiçaria e superstição.

Para o africano bantu, a morte não é, verdadeiramente, a negação da vida, mas antes uma simples mutação. Por isso, na cultura bantu, o morto é um "outro ser".

LM - Muitos estudiosos afirmam que a morte é sentida e entendida de uma forma diferente pelas culturas diferentes quando em comparação com o Ocidente. Por outro lado, desde a chegada dos colonizadores, a África está em contato direto com a Europa e, mais tarde, com a América do Norte. $O$ que o senhor acha disso? Esse contato transformou a maneira de o africano se relacionar com a morte? Ou continua a ser diferente?

BC - Apesar de tudo, o comportamento do africano perante a morte não mudou muito, na sua essência. Para ele, apesar da morte causar desordem na comunidade, é uma viagem para o além. A família e a comunidade choram copiosamente o desaparecimento de seu ente querido; assistem todos ao velório; acompanham-no até a sua última morada; veneram a sua alma durante anos, consciente de que assim procedendo ele estará sempre em paz.

As manifestações de tristeza e de pesar variam muito de povos para povos. Em Angola o óbito dura trinta dias; durante esse período de nojo um membro da família (viúva ou viúvo; mãe ou pai; tio ou tia) deve permanecer em casa. Em algumas famílias, a viúva, durante esse período, está de luto fechado e não aperta a mão a ninguém. A partir de 1974, logo após a queda do regime fascista em Portugal e a entrada oficial dos guerrilheiros que constituíam a oposição armada contra o colonialismo português, generalizou-se e perdura até hoje a prática do elogio fúnebre por ocasião dos funerais. $\mathrm{O}$ defunto, ainda que em vida não tenha feito nada de relevante, ou que tenha sido mesmo um vilão, tem direito a loas.

Com o tempo, o uso do traje preto como luto, em Angola, vai desaparecendo; aqui talvez esteja a influência de certas igrejas ou seitas religiosas. O uso do fumo está praticamente extinto.

De qualquer modo, reconheço que, hoje em Angola, não já por efeito da colonização, mas da guerra que se lhe seguiu, primeiro, depois por conta da globalização, as mudanças sócio-culturais a que já me referi geraram novas atitudes e comportamentos perante a morte. Por exemplo, nos centros urbanos os óbitos deixaram de mobilizar ondas de solidariedade ante a família do defunto, como antigamente; os cemitérios, por ocasião do Dia dos Finados, embora continuem a ser locais de veneração aos mortos, são também espaços de muita algazarra perpretada por jovens mal educados.

LM - Desde a independência, o senhor esteve envolvido com política, ocupando importantes cargos. $O$ senhor poderia falar um pouco sobre a sua vida política? $O$ senhor acha que ela influenciou a sua escrita literária de alguma forma?

BC - Fui Ministro, fui Embaixador, fui Governador de Província; actualmente sou Deputado à Assembleia Nacional. Tudo isso passa, mas o escritor permanece. A minha vida política influenciou, certamente, a minha escrita literária. Por estar envolvido na política domino melhor certos aspectos da vida social e económica do meu país. Mas a política não corrompeu o escritor. 
Antes pelo contrário; se há algo que, enquanto político, não posso dizer, como escritor digo-o sem qualquer constrangimento. E nunca fui incomodado por quem quer que seja pela crítica social que faço nas minhas obras. Essa liberdade ninguém ma pode tirar; só mesmo a morte.

LM - Considero que todos os seus livros apresentam esperança, em maior ou menor grau. Essa esperança tem relação com o fato de o senhor seguir na vida política?

BC - Acho que não. Aqui sou eu enquanto Autor que considera que há sempre uma saída para a crise. Como o povo diz, "enquanto há vida, há esperança".

LM - A literatura (principalmente a poesia) foi muito importante na luta pela independência de Angola. E hoje, como o senhor enxerga a literatura em Angola? Ainda existe uma preocupação com o social? E a sua literatura?

BC - A literatura angolana continua pujante. Em todas as gerações literárias há sempre a preocupação com o social. $\mathrm{O}$ escritor critica o que não acha correcto e perspectiva a mudança do país em todos os aspectos.

Antes era a crítica à situação colonial em que vivíamos. Com a independência de Angola, em 11 de Novembro de 1975, a literatura ganha novos rumos. Um mês após a proclamação da independência, é fundada a União dos Escritores Angolanos, cujos órgãos sociais são maioritariamente constituídos por escritores que vêem das cadeias, da guerrilha, da luta clandestina e da oposição civil.

Sem nunca deixar de exercer o seu papel de formador de consciências - na expressão feliz do Poeta-Presidente Agostinho Neto -, também os escritores vão se mantendo atentos e com voz crítica, deixando aos poucos de exercer funções no poder político e procurando questionar múltiplos aspectos da realidade social.

Hoje critica-se os modos de governação. Acho que essa crítica mais ou menos aberta começou na década de 1980 com "Quem me dera ser onda", de Manuel Rui, e o "Cão e os Calús", de Pepetela.

Os 80 marcaram, com efeito, o início de um ciclo de discussões, de debates e de fóruns onde a classe intelectual rediscute rumos e definições, pondo em causa algumas das opções essenciais e exigindo uma maior abertura que vai desembocar na década seguinte, com o fim do sistema monopartidário e a implantação da Segunda República, em 1991, de cariz multipartidário. É nessa década que se funda a Brigada Jovem de Literatura e desponta uma outra geração literária. Regista-se, então, uma grande de diversidade de temas, o aparecimento de de novos escritores, de correntes diversas, resultantes da contradição entre a utopia sonhada e a praxis política.
Sobressaem como escritores, nessa geração, João Melo, Paula Tavares, Carlos Ferreira, João Maimona, Luís Kandjimbo, Lopito Feijó, António Fonseca, José Luis Mendonça, Irene Neto, Rui Augusto, São Vicente, Tiago de Buca, António Gonçalves e José Eduardo Agualusa. Esses novos escritores atingiram hoje a maturidade literária e estão em plena fase de criação.

Como ontem, a literatura angolana hoje é responsável pela formação de uma consciência nacional e crítica. Nas suas obras literárias os escritores angolanos acabam por desenhar os vários sentidos da nação; abordam o lado histórico do percurso da nação, reinventado novos modos de encarar o passado, ou até mesmo desconstruindo dogmas pretensamente históricos.

Hoje, num país diferente e a trilhar pela senda do desenvolvimento, Angola é uma força aglutinadora, democrática e diversificada, com escritores das mais variadas origens e proveniências, unidos no amor comum à terra angolana, civicamente activos e interventivos.

A literatura angolana atingiu a plena maturidade e nível estético de excelência. É essa uma das razões que justifica a proclamação no próximo mês de Setembro da Academia Angolana de Letras.

LM - O senhor acha que o fato de ter participado ativamente da Guerra de Libertação mudou a forma como senhor enxerga Angola? E qual o peso dessas experiências para a sua escrita literária?

BC - Eu sou da clandestinidade; nunca fui militar. De qualquer modo, dei a minha modesta contribuição na luta contra a dominação colonial. O signo do fogo é o livro em que essa faceta da minha vida política está mais evidente.

LM - E quais são as suas lembranças da Guerra Civil? Não pensa em escrever um livro parecido com $O$ signo do fogo, mas sobre a Guerra Civil? Já li diversos romances relatando as consequências desse combate (a falta de água e de luz, o desabastecimento, o medo constante), mas nunca sobre o cotidiano dos homens que lutaram ou que se envolveram de alguma forma com a guerra.

BC - Não. Mas tenho memórias dessa guerra. Aconselho-a a ler Noites de Vigília, o meu último romance.

De qualquer modo, em $O$ signo do fogo intentei desvendar de modo simbólico o inexplicável e o implícito no comportamento de vários sujeitos do processo de libertação nacional. Esse desvendar de segredos, faz-se com recurso ao signo do fogo. O fogo é, assim, símbolo de força, de vida e de morte. O fogo é amor e cólera, interior e exterior, macho e fêmea, chama purificadora, acção fecundante, construção e destruição. Nesse romance o ferreiro não é senão um demiurgo a quem cabe auxiliar os nacionalistas angolanos na sua luta 
contra as autoridades coloniais de então. Ao ferreiro compete antever, preanunciar e insinuar toda a trama da história.

LM - Como o senhor enxerga a nova geração de escritores angolanos e a relação da sua produção literária com a construção de Angola? A geração que não viveu a Guerra pela Libertação ou que era muito jovem nessa época? Em uma entrevista, publicada no livro Nação e narrativa pós-colonial, o senhor afirma que a luta pela independência era o que movia os escritores da geração que viveu essa guerra, mas que não é mais o que move os da nova geração. $O$ que move esses novos escritores?

BC - A nova geração de escritores angolanos continua, no fundo, na senda das gerações anteriores: a fazer crítica social.

Mas é preciso ter em conta que a sociedade angolana, como todas as sociedades, tem a sua própria dinâmica. Os angolanos hoje vivem em paz, mas tiveram de enfrentar uma guerra de longa duração (27 anos) desde a proclamação da independência em 1975. As principais infra-estruturas foram destruídas durante o conflito armado; milhares de famílias foram desestruturadas; aumentou exponencialmente o número de viúvas, de órfãos, de crianças abandonadas; igualmente de mutilados. Houve um movimento migratório de populações de zonas afectadas pela guerra para os grandes centros urbanos; muitos angolanos emigraram para o exterior dos país. As cidades cresceram muito e de modo anárquico; concomitantemente crescerem os índices de criminalidade e de violência doméstica.

A partir de 1991, Angola deixa de ser um regime de partido único; instala-se a democracia multipartidária. Realizam-se em 1992 as primeiras eleições gerais; a oposição armada perde nesse pleito eleitoral e retoma a guerra; Luanda, a capital do país, foi palco de violentos combates. A guerra, de novo, alastrou-se a todo o país e só termina em Fevereiro de 2002 com a morte em combate do líder da oposição armada.

Com a paz definitivamente alcançada em 2002, Angola tem passado por uma fase de reconciliação entre os seus cidadãos outrora desavindos por questões políticopartidárias; o país sara as suas feridas e reconstrói-se em todos os aspectos. Tudo isso são processos que duram anos, talvez décadas. Seja como for, ficam as memórias da guerra e as suas consequências que ainda prevalecem. É disso que falam os escritores angolanos hoje, quer sejam de gerações anteriores, como de gerações mais novas.

LM - A família de muitos angolanos tem origem portuguesa - o que é inevitável depois de tantos anos de colonização e contato. Como acomodar essa herança, que foi cruel, mas intensa, em um país que conquistou sua independência há tão pouco tempo? BC - O povo angolano é, por natureza, generoso e acolhedor. Quarenta anos depois da proclamação da independência, passaram os ódios entre os angolanos e os antigos colonizadores. Há milhares de jovens que não tem ideia nenhuma do que foi o colonialismo português em Angola.

A amizade entres os povos angolano e português é muito forte. Durante a luta de libertação nacional, o MPLA, partido no poder e de que sou militante, dizia e defendia que a nossa luta não era contra o povo português mas sim contra o regime fascista de Salazar e de Marcelo Caetano.

$\mathrm{Na}$ histórica vitória de Portugal sobre a França, na recente Copa da Europa de futebol, a maioria dos Angolanos festejou o facto inédito com muita alegria e entusiasmo.

$\mathrm{Na}$ amizade entre os dois povos é de realçar o factor língua. É também por essa via que se entende o à vontade com que os brasileiros convivem harmoniosamente com os angolanos aqui em Angola. A Língua Portuguesa é assumida, desde a proclamação da independência, como sendo a língua oficial de Angola.

Há, na sociedade angolana, muitos hábitos e costumes portugueses; está bem patente entre nós a herança cultural portuguesa. Os escritores angolanos, em particular, convivem muito bem com essa realidade. Sem deixarem de ser angolanos e, obviamente, africanos, reapropriam-se do português e dão-lhe um novo acento. Basta lembrar, neste particular, Luandino Vieira - o nosso grande mestre da língua literária angolana recriada.

$$
\text { *** }
$$

\section{PEPETELA}

LuARA Minuzzi (LM) - Surge uma aproximação entre a teoria socialista e religião católica em dois dos seus romances - Yaka e Mayombe. Essa é uma coincidência ou o senhor realmente acredita que existe uma relação entre os dois?

Pepetela (P) - Acho que de facto há pontos em comum, no que diz respeito particularmente ao que se associa a Jesus Cristo, amigo dos pobres e oprimidos, desconfiando dos ricos e poderosos, ou, pelo menos, guardando distância deles, com as posições dos socialistas. Por outro lado, é muito curioso que a estrutura da Igreja Católica seja tão semelhante, embora com nomes diferentes, da estrutura dos Partidos Comunistas (o sínodo dos cardeais e o comité central, a infalibilidade do líder, os Concílios de um lado, os congressos do outro, etc.) Dá ideia que os partidos sociais-democratas do Século XIX se inspiraram 
nessa estrutura da Igreja. Claro que sobre a Verdade Única, ou Única Religião Verdadeira e a única teoria verdadeira da sociedade, caindo muitas vezes no totalitarismo e na intransigência mais fundamentalista, também existem similitudes estranhas. Marx tem uma frase (não a tenho presente por isso só posso dar a ideia e não a citação) em que se declarava fascinado pelo religioso que estava contido na política.

LM - Já ouvi que o senhor não tinha medo de morrer na Guerra pela Libertação de Angola, pois tinha o corpo fechado. Isso é verdade? Fico pensando em Mayombe e no ceticismo de Sem Medo e de João e, por isso, sinto curiosidade em saber. Tem uma cena em que um dos guerrilheiros pede para ir caçar, pois havia visto um pássaro de boa sorte, e Sem Medo pergunta ao Comissário Político quando ele acabaria com essas "superstições". Na verdade, há muitas sátiras em relação ao racionalismo pregado pelos comunistas (nos livros de Boaventura Cardoso, por exemplo, os camaradas do partido tornam-se cômicos por isso). Nesse sentido, gostaria de saber também como ocorria na prática a adaptação de uma doutrina voltada para a razão a uma tradição africana, que lida muito com o transcendente.

P-Foi sempre um aspecto muito delicado. É claro que eu não acreditava nada que tinha o corpo fechado, mas tinha de parecer para dar confiança aos meus homens. Como poderiam eles seguir um tipo em que não confiavam? Sempre que era possível, tentava-se "educar" as pessoas, mas apenas para casos importantes. Há crenças que podem ser verdadeiramente prejudiciais ou perigosas. Essas merecem explicações racionais para serem afastadas. Há outras sem grande relevância para a luta. $\mathrm{O}$ melhor é deixar, não se envolver numa discussão complicada. O bom senso ditava a posição em determinado momento. É difícil, claro. Uns tinham mais sucesso que outros.

LM - Inúmeros romances seus mencionam a Guerra de Libertação, mas apenas um (Mayombe) trata exclusivamente da guerra, do cotidiano dos guerrilheiros, das dificuldades enfrentadas pelo movimento. Tendo esse sido um momento vivenciado pelo senhor (e, imagino, um momento muito importante da sua vida), me pergunto por que ele não surge mais em seus escritos literários.

$\mathbf{P}$ - De vez em quando essa vivência pode "infiltrar-se" em outros escritos, mas de forma camuflada, pois é uma experiência que marca definitivamente. Sinto por vezes isso ao escrever determinada cena, que pode não ter nada a ver com guerra, mas tem sempre com alguma estratégia. Portanto, se não aparece mais a Guerra de Libertação, é por ser conscientemente que quero tratar outros assuntos e não isso. Não tem sido por falta de provocação por parte de algumas pessoas ou até antigos companheiros. Digo sempre o mesmo, outros que escrevam sobre essa luta. Embora Parábola do Cágado Velho tenha cenas de guerra, ou o meu último livro também, já são outras guerras, não aquela. Começou com Muana Puó, Mayombe, As Aventuras de Ngunga, parte da Geração da Utopia. Acho que chega.

LM - Eu percebo uma mudança no tom de seus romances. $\mathrm{O}$ primeiro, Mayombe, na minha opinião, é uma história de muita esperança. Claro que existem denúncias dos problemas ocorridos dentro do MPLA, do tribalismo, da corrupção. Mas eu vejo o final como sendo muito esperançoso, cheio de utopia. Depois, essa esperança se perde bastante e um romance bastante significativo nesse sentido é Geração da utopia. Assim como a sua literatura, essa foi uma mudança pela qual o senhor passou?

$\mathbf{P}$ - Em Mayombe eu já tinha muitas dúvidas sobre tudo o que se andava a fazer e há frases que são elucidativas e têm sido muito referenciadas. Mas, claro, havia a esperança de que se poderia mudar ainda alguma coisa, "salvar os móveis", dependendo muito da nova geração. Mas esta não se mostrou melhor que a anterior e o choque com a realidade pura e dura foi muito claro um ou dois anos depois de eu ter acabado o livro, quando os mais jovens se mostraram em toda a sua plenitude.

LM - Também fico pensando se Sem Medo não teria se transformado em Aníbal, caso tivesse sobrevivido à guerra. Acredito que a morte de Sem Medo é quase necessária para a sua caracterização como herói. $O$ senhor pensou nisso enquanto escrevia? Como foi o processo de escrita de Mayombe? Alguns aspectos do romance foram revistos nessa década que se passou entre a escrita e a publicação?

$\mathbf{P}$ - Começo pelo fim: o livro foi publicado exactamente como foi escrito, embora tenha havido um intervalo de quase dez anos. Só corrigi uma ou outra palavra, uma ou outra frase, por questões meramente estéticas. Provavelmente Aníbal é um Sem Medo que sobreviveu à guerra, acho que sim. O Sem Medo pedia-me para morrer e eu matei-o, antes do fim do livro. Depois escrevi a parte que levava a esse fim. Ele bem dizia que nunca se adaptaria ao futuro que adivinhava. E tinha razão. Por isso lhe fiz a vontade. Por isso tem aura de herói trágico, como diz o comissário no fim. Tudo isso foi portanto consciente.

Eu ia escrevendo, sem saber muito bem o que faria a seguir. À medida que alguns factos relevantes surgiam no meu dia-a-dia, eu introduzia de forma ficcionada no que escrevia à noite ou uma semana depois. Fui aprendendo a escrever esse romance enquanto o escrevia. E ia pensando 
e aprendendo sobre o que me rodeava. Foi para entender essa realidade, de facto, que escrevi. Ou que escrevo.

LM - O senhor atuou por algum tempo na política de Angola, tendo sido, inclusive, vice-ministro da Educação. Como foi a sua carreira política? Por que o senhor desistiu?

$\mathbf{P}$ - Nunca apreciei a minha carreira política, nunca gostei dos jogos necessários da política, e nunca gostei do Poder ou sequer de estar perto dele. Mas sempre fui fascinado por estudar os meandros da política. Os homens e mulheres na acção e nas manobras de bastidores e nas meias verdades e nas traições. Tudo o que se sabe. Para mim era apenas matéria interessante enquanto material de estudo para escrever sobre isso depois. Desisti quando estava demasiado farto da burocracia e porque queria escrever. Era cada vez mais difícil de conciliar as duas actividades, até porque, como escritor, era demasiado crítico do político que tinha de ser. Por isso fui procurar uma actividade onde poderia conciliar mais facilmente a escrita. Virei professor.

LM - Em uma entrevista, o senhor diz que muitos dos personagens e situações de Mayombe foram inspirados nas suas vivências da guerra. $O$ senhor poderia dar alguns exemplos? Há algum personagem com o qual o senhor se identifique?

$\mathbf{P}$ - Não é propriamente uma personagem com a qual me identifique mais, mas obviamente que o Sem Medo me é muito próximo sentimentalmente. Ou Muatiânvua. $\mathrm{Ou}$ mesmo as fraquezas-força de Teoria. Ou a Ondina que perturbou gerações... As situações, sim, são algumas que vivenciei, sempre com ficção no meio. A guerra naquele momento naquela região passava-se como no livro. Nunca ninguém veio dizer que exagerei ou falseei as situações e as contradições denunciadas, porque aquela era a realidade.

LM - O senhor acha que o fato de ter participado ativamente da Guerra de Libertação mudou a forma como o senhor enxerga Angola? $E$ qual o peso dessas experiências para a sua escrita literária?

$\mathbf{P}$ - Certamente que a experiência faz as pessoas verem as situações de forma diferente de antes. E isso também acaba por ter o seu peso na literatura. Mas eu serei o pior crítico de mim próprio, deixo isso para os leitores.

LM - Quais são as suas lembranças da Guerra Civil? Não pensa em escrever um livro parecido com Mayombe, mas sobre a Guerra Civil? Já li diversos romances relatando as consequências desse combate (a falta de água e de luz, o desabastecimento, o medo constante), mas nunca sobre o cotidiano dos homens que lutaram.
$\mathbf{P}$ - Tenho um ou outro ponto sobre a Guerra Civil, mas não tenho intenção de a dissecar, de entrar nela totalmente. Acho que há muita gente que participou. A eles de usarem esse filão.

LM - Como o senhor enxerga a nova geração de escritores angolanos e a relação da sua produção literária com a construção de Angola? A geração que não viveu a Guerra de Libertação ou que era muito jovem nessa época?

$\mathbf{P}$ - Tem havido muitos problemas para escritores mais jovens, com dificuldades de edição particularmente. Há talentos que despontam, mas poderiam ser mais conhecidos se vivessem em países mais desenvolvidos ou se escrevessem em francês, inglês ou espanhol. Temos essa grande barreira à publicação, sobretudo os mais jovens.

LM - Lendo Mayombe e, depois, Geração da utopia, fico realmente triste junto com os personagens pela perda de um sonho tão bonito e esperado por tanto tempo. Para o senhor, o que deu errado em Angola? O tipo de economia escolhida? A forma como foi posta em prática?

$\mathbf{P}$ - Seria preciso um livro para explicar tudo isso! E há alguns que dissecam a petro-dependência, por exemplo. Cometemos muitos erros, alguns evitáveis. E a conjuntura internacional também nunca foi favorável. Angola conseguiu a independência, essa é uma vitória. Não é suficiente? Não, mas foi o possível.

LM - Como o senhor enxerga Angola no futuro? Qual o papel da literatura e, em especial, da sua literatura para a construção desse futuro?

$\mathbf{P}$ - É um país que tem realmente muitas possibilidades para dar certo. Mas precisamos de tempo. Tempo para pensar no tipo de sociedade em que queremos viver e que nos deixem estruturá-la. Para isso é preciso tempo e muita gente a discutir calmamente. A literatura entra também nesse debate, faz pensar, levanta problemas.

LM - Depois de Mayombe e de seus comandantes descrentes do que eles designam por "superstições", em muitos de seus livros, a tradição dos povos originais de Angola é resgatada - a máscara em Yaka, a história de Lueji no romance homônimo. Como o senhor enxerga essa questão da modernidade e da tradição? Qual é ou qual deveria ser o espaço dos dois em Angola?

P - A tradição faz os angolanos serem eles próprios, particulares, e por isso deve ser conhecida e questionada, sem complexos nem arrogância. Mas os angolanos vivem num mundo que evolui e portanto têm de evoluir com ele e adoptar tudo o que de novo vai sendo feito, desde que 
seja favorável ao projecto. É na junção dessas duas forças, e não no seu combate, Tradição-Modernidade, que pode surgir um futuro promissor.

LM - A sua família tem origem portuguesa, assim como a de muitos outros angolanos. Como acomodar essa herança, que foi cruel, mas intensa, em um país que conquistou sua independência há tão pouco tempo?

$\mathbf{P}$ - Como qualquer país que foi colonizado, Angola deve estudar a História, não deixar que ela fique escondida, mas para a superar. Aprender a pensar por si, em função dos seus interesses, mas com um olhar atento para que os outros fazem. Saber evitar que novas dominações externas aconteçam e ajudar os outros a libertarem-se. Fizemos isso com a Namíbia e a África do Sul, devemos continuar com outros, vizinhos ou não. A nossa experiência pode ajudar, por isso é nosso dever passar a mensagem.

$$
* * *
$$

\section{JOSÉ EDUARDO AGUALUSA}

LuARA Minuzzi (LM) - Apesar de você não ter escrito nenhum livro sobre o front de guerra, a Guerra de Libertação de Angola aparece bastante em seus escritos, como em Teoria geral do esquecimento. Também percebi a constância desse tema em outros escritores angolanos. Você acha que existe alguma fixação com o tema da guerra devido a essa constância? Como você explicaria esse fenômeno?

José Eduardo Agualusa (JEA) - É impossível escrever sobre Angola, nos últimos 50 anos, iludindo a guerra por completo. A guerra estava lá. Sempre me lembro da guerra, desde criança. Não se trata de fixação, seria como escrever sobre o Rio de Janeiro sem em algum momento falar no mar.

LM - Você era bastante novo durante a Guerra de Libertação de Angola. Ter passado a sua infância em meio a um evento histórico tão importante modificou a forma como você enxerga e se relaciona com Angola? E seus textos literários foram modificados? Ou você acha que, por ser tão jovem, isso não foi tão marcante?

JEA - Naturalmente. Passei toda a minha infância e adolescência em Angola e sempre me lembro da guerra. $\mathrm{O}$ meu pai trabalhava no CFB. Dava aulas aos trabalhadores ao longo da linha do caminho de ferro. Tinha um vagão especial, que era uma espécie de apartamento sobre rodas, com sala de aulas. Eu e a minha irmã costumávamos viajar com ele, nas férias, e várias vezes assistimos a ataques da guerrilha. Não havia como ignorar a guerra.
LM - E em relação à Guerra Civil? Você acha que essa prolongada guerra modificou seus escritos literários?

JEA - Também, é claro. Eu fui jornalista. Fiz alguma reportagem durante a guerra. Foram anos muito intensos.

LM - Li diversos romances relatando as consequências da Guerra Civil (a falta de água e de luz, o desabastecimento, o medo constante), mas nunca sobre o cotidiano dos homens que lutaram ou que se envolveram de alguma forma com a guerra. $O$ que você pensa disso? Será que existe alguma explicação para esse fenômeno?

JEA - Existe ainda pouca literatura sobre a guerra. Lembro o romance do Sousa Jamba, Os Patriotas. Uma visão da guerra civil do lado da guerrilha. Acho que com o tempo irão aparecer outros livros. Agora há muita literatura de testemunho, sobretudo do lado da guerrilha, mas ainda não há ficção.

LM - Você considera o romance Teoria geral do esquecimento um livro sobre a Guerra de Libertação de Angola? Mesmo que a independência ocorra no início do romance, fico pensando que, para Ludo, as questões principais da guerra (colonialistas $\times$ colonizados, por exemplo) surgem a partir da independência. É como se ela não tivesse consciência desses problemas anteriormente. Além disso, há também vários flashes do passado de outros personagens, como o de Pequeno Soba. Qual a sua opiniões sobre isso?

JEA - Não é um livro sobre a guerra civil, nem sobre a guerra de libertação. É um livro sobre xenofobia e o medo do outro. A guerra está lá apenas como pano de fundo.

LM - Ainda sobre Teoria geral do esquecimento, por que você escolheu contar a história a partir da perspectiva de uma portuguesa, de alguém, a princípio, do lado da metrópole, da opressão? Qual foi a inspiração para o romance?

JEA - Exatamente porque é um livro sobre o medo do outro. Aquela mulher isola-se por pura xenofobia. Porque o outro a aterroriza. Só se salva quando se transforma nesse outro.

LM - Ludo tem medo do céu e, em Barroco tropical, uma personagem afirma que os anjos são uns bichinhos muito filho da puta. Parece que, em alguns de seus romances, os valores do alto despencam, se desvalorizam - há como uma inversão. Você concorda com essa afirmação?

JEA - Nunca tinha pensado nisso. Pode ser. 
LM - Percebo que, principalmente em Barroco tropical, essa inversão está ligada a um pessimismo em relação ao futuro de Angola. Aqueles que detêm o poder, por exemplo, que estão tão no alto da hierarquia que são quase como deuses, preocupam-se apenas consigo mesmos, esquecendo a população que deveriam proteger. $O$ que você pensa sobre isso?

JEA - Não creio que a generalidade dos meus romances seja pessimista. Talvez apenas o Barroco Tropical. Acho a Teoria geral do esquecimento um livro muito otimista. A maior parte dos personagens têm uma segunda oportunidade e aproveitam-na.

LM - Muitos estudiosos afirmam que a morte é sentida e entendida de uma forma diferente pelas culturas africanas, quando em comparação com o Ocidente. Por outro lado, desde a chegada dos colonizadores, a África está em contato direto com a Europa e, mais tarde, com a América do Norte. $O$ que você acha disso? Esse contato transformou a maneira de o africano se relacionar com a morte? Ou continua a ser diferente? JEA - A maioria dos africanos são hoje cristãos. Então, é claro que mudou.

LM - A literatura (principalmente a poesia) foi muito importante na luta pela independência de Angola. E hoje, como o senhor enxerga a literatura em Angola? Ainda existe uma preocupação com o social? E a sua literatura?

JEA - Eu tenho essa preocupação e acredito que a maior parte dos escritores angolanos também. Acho isso bastante óbvio. Os escritores tentam usar os seus livros como espaços para criar debate sobre temas atuais.

LM - E como você enxerga essa relação de escritores mais velhos, que viveram a Guerra de Libertação? Você acha que aprendeu alguma coisa com eles?

JEA - Sim, claro. É uma literatura que discute questões de identidade que continuam atuais.

LM - Como você enxerga Angola no futuro? Qual o papel da literatura e, em especial, da sua literatura para a construção desse futuro? Qual o papel dos novos escritores nesse processo?

JEA - Não sei. Não faço ideia. Gosto de pensar que a literatura melhora as pessoas, que um bom livro é sempre transformador, mas a verdade é que ainda se lê muito pouco em Angola. A influência do livro é muito reduzida.

LM - A família de muitos angolanos tem origem portuguesa - o que é inevitável depois de tantos anos de colonização e contato. Como acomodar essa herança, que foi cruel, mas intensa, em um país que conquistou sua independência há tão pouco tempo?

JEA - Acho que isso hoje é relativamente tranquilo. Há angolanos de origens muito diversas: de origem portuguesa, cabo-verdiana, são-tomense, goesa, congolesa, etc. E há cada vez mais a mistura de tudo isso.

LM - Angola é um país com uma tradição de escritores que também ocupam cargos políticos no país. Agostinho Neto, Pepetela e Boaventura Cardoso são apenas alguns exemplos. Você nunca pensou em seguir carreira política? Pensa em alguma explicação para o fenômeno?

JEA - Tenho horror à ideia. Sou muito feliz fazendo o que faço - escrevendo. Não tenho chefes, não tenho horários, posso escrever onde quiser. E fazendo o que faço posso também ajudar a criar diálogo e a transformar o mundo.

$$
* * *
$$

\section{ONDJAKI}

LuARA Minuzzi (LM) - Em Os transparentes, o narrador comenta que existe uma fixação, uma paranoia com a guerra em Angola. Você acha que isso realmente ocorre até hoje? Você se sente assim, com o pensamento quase que fixo na guerra? Se sim, o que essa fixação mudou na sua escrita literário? Como influenciou?

ONDJAKI (O) - Penso que você está a trazer a questão para pessoas diferentes... O que o narrador acha ou diz, é uma coisa. $\mathrm{O}$ que eu, enquanto pessoa ou cidadão penso, poderá ser outra.

Eu, o cidadão, não sei se as pessoas ainda têm uma paranóia com a guerra. Parece-me simples deduzir, no entanto, que a guerra em sendo tão recente e tendo sido tão longa, ainda co-habite no nosso imaginário, consciente ou inconsciente. Mas assumo que as deduções são exercícios perigosos.

Eu não tenho nem nunca tive o pensamento quase fixo na guerra. Mas nasci em tempo de guerra. Quando a guerra terminou em 2002, eu teria uns 25 anos. Para quem estava em Luanda, a guerra era sobretudo um rumor longínquo. Mas se pensarmos numa Angola colectiva, numa entidade chamada "o país", então sabemos que estávamos e estivemos todos em guerra. E sabemos que foram e estavam a ser várias guerras, diferentes intervenientes, de fora, de dentro, de antes e de um presente recente. Se considerar que muitas pessoas não podem ser indiferentes à guerra, ainda que a guerra não lhes chegue à pele no dia a dia, então podemos ir até à minha dedução de que a guerra andou a habitar-nos por fora e por dentro enquanto esteve activa; e agora, que 
não há essa guerra de fora, deve haver outros contornos internos que são feridas, dores, cicatrizes internas mais ou menos pessoais, mais ou menos nacionais, mais ou menos visíveis.

Não penso que a guerra tenha influenciado apenas a minha escrita. Penso que terá influenciado a escrita de todos na literatura angolana. E, claro, penso também que a guerra terá influenciado a vida de todos os angolanos. Mesmo os que menos se afectaram directamente com esse fenómeno.

A questão do narrador de Os transparentes, penso eu, porque também não o conheço bem, não sei bem quem foi que andou a narrar nesse livro, é que ele andou a observar outras coisas. E no livro ele diz as coisas que andou a observar e que quis "anotar", e muitas são deduções dele. Não minhas. Não quero retirar o meu 'papel' de autor, não se trada disso. Quero apenas dizer que as visões e leituras de um narrador nem sempre são as minhas, as do cidadão

[Mas se quer que lhe diga, não ando com o meu pensamento preso na guerra. Mas mantenho a convicção e o pressentimento de que teremos que falar da guerra, torná-la ainda mais íntima, saber dizer-lhe que sendo tão dura e tendo sido tão horrenda, é necessário que nos sentemos, mais-novos, mais-velhos, e ela mesma, para falar da guerra. Das guerras. Do que foi que tivémos que atravessar para aqui chegar (refiro-me à paz), mas aceitando e deixando que a cicatriz afectiva nos diga sobre as coisas (as pessoas, os mundos) que deixámos no caminho dessa travessia. A guerra é talvez uma travessia invísivel e nebulosa, não porque faça escuro, mas porque não há tempo de olhar para os lados ou para trás. É no outro lado da travessia que contabilizamos quantos dedos nos faltam, ou memórias, ou filhos, ou maridos, ou pais, ou partes da nossa dignidade e das nossas crenças no ser humano.]

LM - Sei que a Guerra Civil fez parte da sua infância. Entrevistas suas explicam como $O$ s da minha rua, Bom dia camaradas e AvóDezanove e o segredo do soviético resgatam algumas dessas memórias misturadas com ficção. Porém, esses livros me passam a sensação de uma infância normal e feliz em uma cidade na qual os confrontos diretos não chegaram - apesar de chegarem as consequências das prolongadas lutas, como a falta de água. Já em Os transparentes, acho que o tom muda. Mesmo que se relate um período posterior à guerra, sinto esse romance muito mais pessimista em relação aos rumos de Angola. Essa é uma mudança pela qual você passou de criança para adulto? Ou é simplesmente outra forma de relatar a realidade?

$\mathbf{O}$ - Eu realmente ainda penso que a escrita vem das ideias literárias. O começo. A raiz. É por aí que eu gosto de começar. E o tom dos 'transparentes' é diferente porque a própria ideia literária é diferente, é um projecto bem distinto de Bom dia camaradas ou Os da minha rua. Mas também porque se acumularam algumas coisas em mim e que foram rebentar nessa direcção que aparentemente traz mais pessimismo. Ou mais realismo.

São formas diferentes de relatar a cidade, porque passou tempo, e porque a cidade mudou. A política mudou e os políticos sobretudo mudaram e muito. Não são apenas as influências externas (a globalização...) que foi chegando, mas também as coisas de dentro (as nacionais) que transformaram o país e a cidade de Luanda. Os transparentes falam de uma época menos inocente, talvez, e penso que nisso estou de acordo com o narrador (e até com alguns dos personagens): a indiferença, a incompetência, a corrupção, o egoísmo estão a vencer. Sobretudo os políticos, mas também o cidadão comum foi-se vestindo de uma capa de indiferença que é muito perigosa. Mas essas capas são também (talvez...) trazidas pela própria realidade. Quando o Odonato diz "este é o corpo que eu agora tenho", eu fico a pensar na cidade de Luanda, entristecida, a dizer a mesma frase sobre o corpo dela. E o corpo de Luanda somos todos nós.

Luanda, os personagens, neste livro, são mais duros sim. É um narrador nada inocente, talvez magoado com o que vê no "corpo da sua cidade", e que vai contrastar muito com os narradores de Os da minha rua ou Bom dia camaradas. Mas por isso lhe digo que eu acho que não é o mesmo narrador. Quase nem mesmo o mesmo escritor..

O "tom" muda em Os transparentes porque tudo mudou. Sobretudo as pessoas que mandam e os que são mandados. Mas há laivos de esperança, há faróis de possibilidades que imediatamente se acendem. E eu gostaria de estar atento a isso também.

Eu não pude escrever outro livro com os materiais que eu tinha dentro de mim. Tentei agarrar-me à beleza do VendedorDeConchas e de Odonato, mas vence a crua estória de Paizinho ou a da indiferença dos nossos dias. Eu não pude escrever outro livro e também me doeu fazer aquele, mas era a minha escrita a ir de encontro aos ecos internos.

LM - Como exemplo dessa diferença citada anteriormente, é possível comparar as explosões que ocorrem em AvóDezanove e o segredo do soviético e em Os transparentes. As duas explosões iniciam os romances, apesar de ocorrerem realmente apenas ao fim dos enredos. A primeiro explosão, porém, é descrita com alegria e otimismo. As crianças brincam e todos olham os fogos de artifício colorindo o céu. A segunda traz a morte, o desespero. Essa repetição da explosão, do fim pelo fogo foi proposital? Tem algum significado? 
O - Concordo que em AvóDezanove e o segredo do soviético o fogo é celebrativo, sobretudo porque vem, digamos, da mão das crianças. Mas o fogo, venha de onde vier, e manipulado por quem seja, tem a caracteristica de ser quente e destruidor. Mas na PraiaDoBispo é intenção das crianças usar o fogo como instrumento de poder contra um outro poder. É o feitiço a virar-se contra o feiticeiro. E eu acho que o feiticeiro-inimigo dessas crianças são os adutos, não necessariamente russos ou outros.

Em Os transparentes não sei se sei de onde veio o fogo. No sentido de ser um fogo bem maior, abrangente, e que irá, espero eu que assim tenha sido, feito algum tipo de trabalho. Porque é o fogo quem também traz a cinza, e é das cinzas que se pode esperar um qualquer 'renascer'. Sim, penso que tem algum significado o uso do fogo. E não penso que seja a última grande desgraça que acontece a Luanda nos meus livros. Houve grandes chuvadas em Quantas madrugadas tem a noite, e o fogo em Os transparentes. Pode ser que Luanda não resista da próxima (terceira; última...?) vez...

Há uma coisa que me surpreendeu ao ir escrevendo este livro. As coisas foram-se refazendo no tempo. Por isso não me reconheço como sendo dono de tudo aquilo, estava muita gente a trabalhar ali, personagens, $o$ narrador, um outro narrador escondido e a própria cidade de Luanda.

Isto é: o fogo foi decisão dos homens ou de Luanda?

LM - Há muitas semelhanças entre Os transparentes e Os vivos, o morto e o peixe-frito. O segundo foi apresentado, pelo rádio, em 2006, e, mais ou menos seis anos depois, o segundo foi publicado. $O$ morto que ganha peso ao morrer; os namorados no terraço; o prédio. Até mesmo o tom humorístico é semelhante. Você já estava pensando na trama de Os transparentes há bastante tempo? Em caso afirmativo, o que causou a demora da escrita e/ou da publicação?

$\mathbf{O}$ - Eu peço desculpa mas não vejo essa relação entre as duas obras. Talvez porque o Os vivos, o morto e o peixefrito seja algo tão estranho para mim: passa-se em Lisboa. Sim, entendo alguma coisa no caminho do humor e prédio e namoros, mas é circunstancial (para mim).

Não sei se houve demora na escrita. A primeira vez que me ocorre uma parte de tudo isso, está num conto que talvez seja de 1993 ou 1994, e que se chamava apenasmente "Xilisbaba". Já la estava o prédio deles, Odonato (com outro nomte) e Xilisbaba. Era uma estóriazinha, um pouco diferente, mas já havia transparências e a ideia do Odonato de deixar de comer. Mas esse projecto mais próximo do que veio a ser Os transparentes, deve ter sido em torno de 2001. E depois foram os anos a imaginar as coisas, a vivê-las por dentro. a escrita em si, penso que foi em 2009. E um processo de desilusão fez-me passar largos messes sem voltar a ler o livro. O livro saiu, sim, em 2012, e ainda tinha dúvidas sobre ele. E ainda hoje tenho. Paciência.

LM - Aliás, essa questão da morte - e do morto que pesa - me interessa. Muitos estudiosos afirmam que a morte é sentida e entendida de uma forma diferente pelas culturas africanas, quando em comparação com o Ocidente. Por outro lado, desde a chegada dos colonizadores, a África está em contato direto com a Europa e, mais tarde, com a América do Norte. O que você acha disso? Esse contato transformou a maneira de $o$ africano se relacionar com a morte? Ou continua a ser diferente?

$\mathbf{O}$ - Penso que tudo deve ter mudado com esses contactos. Mas eu não sou estudioso de história nem de antropologia, então sei pouco sobre isso. A visão que tenho dessas grandes questões, incluindo a da morte, é algo pessoal que não posso querer englobar na "cultura africana" nem na "ocidental". Não penso que exista uma "cultura africana" para isto ou para aquilo, pois mesmo o modo como a morte (ou deus) se reflecte nas nossas culturas, varia e muito de lugar para lugar.

No entanto, nessa diversidade de países e culturas, a relação com a vida, com a morte, com o outro, com as crianças e com os velhos, sofre alterações (creio eu) mas não ficou "igual" ao que pensamos ser a "cultura europei" ou "ocidental". Tantos séculos de contacto, e nomeadamente pela pressão dos "contactos forçados" têm que fazer alterações e enviesamentos. A grande discussão é saber se podemos aceitar este presente como o resultado de um processo histórico que se atravessou; ou se rejeitamos este "tempo presente da (chamada) cultura africana" e queremos buscar uma certa matriz. Mas realmente isso não são mandiocas da minha lavra.

LM-AAvóKunjikise fala sempre em umbundu, como o narrador explica. Porém, suas falas são registradas em português no romance, mas destacadas pelo itálico. Por que você preferiu não registrá-las em umbundu? $\mathbf{O}$ - Eu não falo umbundu, mas poderia ter pedido a alguém para traduzir. Só acho que poderia originar demasiadas notas de rodapé.

Por outro lado quis fazer isso, ela fala numa outra língua e conversa com as pessoas ainda que as pessoas não a entendam, a conversa flui, talvez porque seja mais importante o que duas pessoas têm para se dizer. E dizem. E chega ao outro mesmo sem a lógica de terem entendido as palavras faladas.

LM - Muitos de seus livros tratam do período da Guerra Civil em Angola, mas nenhum do combate mesmo. Na verdade, já li diversos romances relatando 
as consequências desse combate (a falta de água e de luz, o desabastecimento, o medo constante), mas nunca sobre o cotidiano dos homens que lutaram ou que se envolveram de alguma forma com a guerra. $O$ que você pensa disso? Será que existe alguma explicação para esse fenômeno?

$\mathbf{O}$ - Não sei explicar esse fenómeno. Penso que as pessoas não pensam "tenho que pôr um combate no meu próximo livro". Acho que são as estórias que trazem os combates ou não trazem essa descrição mais áspera do que é a guerra. Por exemplo, esse tema interessa-me, não tanto pelo combate em si, mas o que acontece aos homens antes e depois de confrontos militares. No meu caso, ainda não chegou a altura de escrever detalhadamente sobre isso.

Por outro lado, escrever sobre a guerra é muito delicado. É preciso respeitar os que andaram muito perto de morrer e os que, tendo estado tão perto, morreram mesmo.

LM - A literatura (principalmente a poesia) foi muito importante na luta pela independência de Angola. E hoje, como o senhor enxerga a literatura em Angola? Ainda existe uma preocupação com o social? E a sua literatura?

$\mathbf{O}$ - Penso que para responder à sua pergunta uma pessoa deve ler atentamente "quase tudo" o que é publicado em Angola. E eu não tenho lido esse quase tudo. Do pouco que leio, e salvaguardo aqui uma leitura talvez superficial, penso que a literatura angola esta sim presa ao "social" e ao "real", com algumas excepções, naturalmente.

Tanto na prosa como na poesia, há escritores que se deixam mais levar pelas suas preocupações, e outros menos. E há, como em todos os países, escritores que têm poucas preocupações.

LM - Você acha que o fato de ter vivido a Guerra Civil mudou a forma como enxerga Angola? E qual o peso dessas experiências para a sua escrita literária?

O - Sim, penso que mudou a minha forma de ver Angola e o mundo. E as pessoas adultas. E as crianças. $\mathrm{E}$ as mulheres. E os meus pais. E a História do país e do continente.

Basta falar com alguém da minha geração e que tenha crescido nos anos 80 . Ou alguém que estava em Luanda durante o período de 1992, antes e durante as eleições, durante os combates de 92 em Luanda. As estórias de guerra, as histórias da guerra, os professores cubanos, os soldados russos, as conversas sobre o ANC, apartheid, o camarada Mandela preso na África do Sul, as invasões sul africanas, os cartões para ir comprar comida, o recolher obrigatório, os rumores incerto da guerra, as especificidades de um sistema político marxista leninista desadaptado à nossa realidade angolana, os comícios, as
Tpalavras de ordem, a adaptabilidade dos angolanos às dificuldades, o riso para contornar a desgraça, a desgraça como parte da vida e a vida contada como teatro falado ao fim de tarde nas ruas ou numa festa que atravessava a madrugada até às cinco e tal da manhã, como é que isso não iria afectar a escrita de qualquer escritor angolano...?

LM - E o fato de não ter vivido a Independência, de ter nascido depois? Como você se enxerga em relação aos escritores que viveram esse momento da história de Angola?

O - Sabe, eu já posso morrer descansado um dia destes. Por causa das pessoas com quem me cruzei nesta minha vida. Muitas delas são mais-velhos escritores, não apenas angolanos, mas também moçambicanos, caboverdianos, portugueses, brasileiros e de outras paragens do mundo.

Sempre me dei bem com todos eles, e muitos (refirome aos angolanos) frequentavam a minha casa quando eu era miúdo. Alguns deles foram grandes escritores por terem feito da sua voz literária uma voz que contava também as coisas de um país chamado Angola. Outros deram prioridade a agendas políticas, e outros ainda foram menos habilidosos ou na sua arte ou naquilo que escolheram para contar. Como em qualquer parte do mundo.

Eu diria que tenho uma relação de admiração e de proximidade com muitos desses escritores. Ou porque os li ou porque os conheci, o que não é o mesmo, mas aproxima de qualquer maneira.

Ter nascido depois da independência... Põe-nos (aos minha geração) num lugar de privilégio e de desafio. Vamos ver o que saberemos fazer com isso.

LM - E como você enxerga essa relação de escritores mais velhos, que viveram a Guerra de Libertação? Você acha que aprendeu alguma coisa com eles?

$\mathbf{O}$ - Aprendo coisas com toda a gente. Com eles, aprendo coisas diferentes. E acho que alguns estiveram muito bem no seu modo de contar. É preciso talvez entendermos que eles andavam a cuidar dos seus destinos pessoais e também dos destinos de um processo histórico que lhes caiu ou lhes rebentou nas mãos, nos olhos, no caminho das suas vidas.

Isto não é fácil. Não podemos pensar que os seus erros ou os seus acertos foram fáceis. Não é desculpar; mas contextualizar. Aprendi, portanto, muito com aquilo que disseram ou escreveram, mas esforço-me por ler também as vidas que eles viveram.

LM - Como você enxerga Angola no futuro? Qual o papel da literatura e, em especial, da sua literatura para a construção desse futuro? Qual o papel dos novos escritores nesse processo? 
O - A dados de hoje, Agosto de 2016, é-me muito difícil espreitar para a frente o futuro de Angola. Penso sempre que o "papel" dos escritores é reler o mundo, ou o seu mundo, ou propor algum tipo de releitura. Penso que a cultural, de um modo geral, poderá realmente jogar um papel decisivo na reconstrução de Angola e na construção de uma nova Angola.

Sinto que vivemos um período particularmente delicado e decisivo. Vem desde 2002, intensificou-se em 2011 com questões sociais e políticas muito específicas, e à medida que o tempo avança (e é preciso não esquecer que o tempo avança para todos, até mesmo para o camarada presidente Eduardo dos Santos) Angola está-se a aproximar de uma mudança que já não será muito longe.

Os contornos dessa mudança não sei dizer. Mas como diria um amigo meu, "desconfio que o futuro está muito perto, e não é todos os dias que digo isso".

LM - A família de muitos angolanos tem origem portuguesa - o que é inevitável depois de tantos anos de colonização e contato. Como acomodar essa herança, que foi cruel, mas intensa, em um país que conquistou sua independência há tão pouco tempo?

$\mathbf{O}$ - Não penso que isso fosse uma questão muito complexa para os angolanos. Não para a maioria. Convivemos durante séculos com essa presença (primeiro) e mistura (depois). Portanto não é justo que se pense em "acomodar essa herança", uma vez que ela foi sendo integrada na sociedade muito anos antes da independência.

LM - Angola é um país com uma tradição de escritores que também ocupam cargos políticos no país. Agostinho Neto, Pepetela e Boaventura Cardoso são apenas alguns exemplos. Você nunca pensou em seguir carreira política? Pensa em alguma explicação para o fenômeno?

O - O fenómeno, se pensar nos membros da guerrilha e nos primeiros governos que se formam em Luanda após a independência, é muito simples. Alguns guerrilheiros escreviam. Alguns guerrilheiro ocuparam cargos no governo, então isso teria de acontecer.

Não penso, nunca pensei em seguir política nem políticos. Embora existam momentos em que somos chamados a actuar politicamente (o que é diferente de ocupar um cargo), e muito do que se diz e se escreve seja também político. Sempre estive disponível para colaborar em actividades culturais, o que inclui (e incluirá) colaborações com ministérios de Cultura. Mas poucas vezes me chama, poucas vezes sou consultado e consigo entender o porquê de isso ser assim. Cada um tem que seguir as suas convicções e coerências, e o tempo depois fará o balanço. O tempo e a História, naturalmente.

Recebido: 23 de julho de 2017 Aprovado: 24 de julho de 2017 Contato: laura.minuzzi@acad.pucrs.br 